\title{
EMPIRICAL VALIDATION OF BLUE OCEAN STRATEGY SUSTAINABILITY IN AN INTERNATIONAL ENVIRONMENT
}

\author{
Jiri DVORAK*, Ilona RAZOVA** \\ University of Economics, Prague, Jindrichuv Hradec, CZECH REPUBLIC \\ * e-mail: dvorakji@fm.vse.cz \\ ** e-mail: ilona.razova@gmail.com
}

\begin{abstract}
This article investigates the applicability of blue ocean strategy in regard to low-cost airlines in the civil airline industry. To do so, the commercial offers of selected airlines were compared to validate any attempts to apply the blue ocean strategy concept. This is followed by examining the time limitation of the concept in a competitive environment and is illustrated by the changes in the industry for the past 30 years and a comparison of offers from similar companies. The third issue is the evaluation of the further contribution of blue ocean strategy when it is recognized as time-limited. The importance of first-mover advantage, which could be based on the ability to capture an economy of scale and advantageously shape the market, is also discussed.
\end{abstract}

Keywords: blue ocean strategy, civil airliners, competitiveness, low-cost strategy, first-mover advantage, Ryanair, customer value, value curve.

JEL: M16, L10, L21.

\section{Introduction}

Air transport experienced dynamic growth in the second half of the twentieth century, which continued into the early twenty-first century and still remains a dynamically developing industry today (Doganis, 2006; Wensveen, 2012; ICAO, 2016). The sharp increase in the distances and the volume of passengers were positively affected by the gradual deregulation of this sector (Doganis, 2006; Fu, Oum and Zhang, 2010; Žabokrtský, 2011). A major consequence was the increased cost-effectiveness of carriers because of optimizing the price strategy and the transport links network associated with increased competition (Fu et al., 2010).

Although the greater competition has increased the availability of this service, it has also led to more intense rivalry and thus lower profitability of the sector (Porter, 2008). During this time, many new companies emerged. For the purposes of this article, we divide them according to the nature of the product and how the transport is organized. We chose two major types of airlines: a traditional airline offering a complete package of services and a wide range of available destinations and a charter airline focused on complex groups, which is mainly used by travel agencies as a part of their service (Reichmuth, 2008;
Bonsor, 2001; Doganis, 2006). In Europe, the situation began to change with the emergence of Ryanair in 1985 when it entered the European market with a low-cost airline concept (Barrett, 2004; Thomas, 2013; Ryanair, 2015a). In terms of the nature of the product offered, the company's approach is considered to be the blue ocean strategy (Štverková, Červinka and Humlová, 2012).

The purpose of this article is to verify this classification at the time of the company's entry into the market and the second topic is to verify the limited time validity of this strategy. From this aspect, the last goal is to assess the further development of the business once the blue ocean strategy effect has vanished and to discuss the importance of the first-mover advantage. This could be, for example, the ability to capture an economy of scale and shape the market in an advantageous way (Hill and Hult, 2016).

\section{Theoretical background}

Competitiveness and competitive struggle are as old as business itself. The strategy is not a new phenomenon in terms of the typology of individual strategic approaches (Ansoff, 1957; Johnson, Whittington, Scholes, Regnér and Angwin, 2014; Miles and Snow, 1978; Porter, 2008; Porter, 1998) and others 
nor in terms of the impact of the changes on the competitive environment (Zhang, Peek, Pikas; Lee, 2016; Dagnino and Padula, 2002). There is an obvious growth in the dynamics of such changes resulting from technological changes, the globalization of the business environment, and hypercompetition. The increasing dynamics of the environment influences the ability to react to changes and the meaningfulness of the long-term strategy development (Heijden, 2006). However, the basic idea of a strategic approach remains to gain a competitive advantage (Carpenter and Sanders, 2008) as a prerequisite for competitiveness and economic success.

One of the most widespread approaches to businesslevel strategy is still considered to be Porter's Generic Strategies (Porter, 1998), a concept based on the two main directions: product differentiation and lowcost strategy. In 2005, W. Chan Kim and Renna Mauborg published their work entitled Blue Ocean Strategy (Kim and Mauborgne, 2005a), which introduced a different view of the issue. The authors claim that this is not just another approach to compete for existing customers as the key aim is to create a new sovereign market space, which enables the organization to escape from a direct fight with existing competitors in the so-called red ocean. The main aim is to create a new demand generated by noncustomers who have not yet used the product using a systematic combination of differentiation and lowcost strategies.

However, the work and originality of the concept have been widely criticized by pointing out that it only develops previously published topics (Rao, 2007), such as disruptive innovation changing the essence of competitive struggle (Bower and Christensen, 1995) or new marketing space formulated by Prahalad and Hamel (1990). Blue ocean strategy completely neglects a number of other aspects, such as possible market risks. What happens if others are developing the same idea at the same time? What happens if the strategy goes too far to overcome the company's competencies? Or simply, what if the blue ocean is not ultimately blue and there are no fish that can be caught (Kraaijenbrink, 2012)? There are also polar opinions (Rao, 2007) that completely reject any benefit of the concept. On the other hand, it cannot be denied that the topics discussed are linked through an appealing metaphor to an attractive marketing concept (Simister, 2011).

According to Kim and Mauborgne (2005a, 2005b), the key contribution of this approach is the definition of six principles leading to the formulation and implementation of the strategy. The key points are to create a current market strategy image that will allow the expansion of existing market boundaries and the discovery of common characteristics of noncustomers. The tool for realization is to find a new value curve using four steps that transform the current competitive model. This concept is criticized for its retrospection and is deconstructed in its applicability to uncover the new and real blue ocean. Simister (2011) states that the authors of the strategy look back through "blue glasses" to find successful companies to apply their rules and that the theory lacks a predictive character and only uses the tools to display successful historical examples (Rao, 2007). This critique is followed by a critical study (Kampa, Cziulik, and Amodio, 2012) stating the absence of a clear link between the formulation and implementation of blue ocean strategy. However, our goal is not to create a new strategy or evaluate whether the method can be used to create a blue ocean. In addition, Ryanair launched its strategy long before the blue ocean strategy concept was published, so the retrospective use of tools does not contradict our aims.

In the late twentieth century, the hub and spoke network business model used by large airlines stabilized as a major business model in passenger air transport. The advantages of the model are the ability to serve a dense network of airports to provide passengers with a point-to-point transfer from point $A$ to point $B$ and to ensure that they move along the entire intended route under the auspices of a single transport company. Traditional airlines also rely on providing their customers with a complete package of services both before and during the flight (Bonsor, 2001; Doganis, 2006; Reichmuth, 2008; Wensveen, 2012). Charter airlines were created to meet the demand from travel agencies and concurrently represent a 30\% share of intra-European civil air transport (Doganis, 2006). From a methodical point of view, it is particularly important that the offers of the two major groups of carriers were unified at the end 
of the twentieth century (Reichmuth, 2008). The rise of low-cost air carriers has shifted the balance of power on the European civil airline market. An overview of the share of individual types of airlines in the European market in 1992 and 2015 is provided in Fig. 1.

A low-cost strategy is considered to be the one that works with low operating costs, or at least a lower cost than is common among its competitors, thus enabling it to become the price leader in the market (Barrett, 2004; Macário et al., 2007; Porter, 2008).
However, the Ryanair concept is seen as a more complex change than just Porter's low-cost generic strategy (Štverková et al., 2012).

The basis for success can be observed in the shift from the traditional business model commonly used by airlines towards a differentiated no-frills product offer with limited or no additional services that enable to sell cheap air tickets without the loss of customer satisfaction (Doganis, 2006; Reichmuth, 2008).

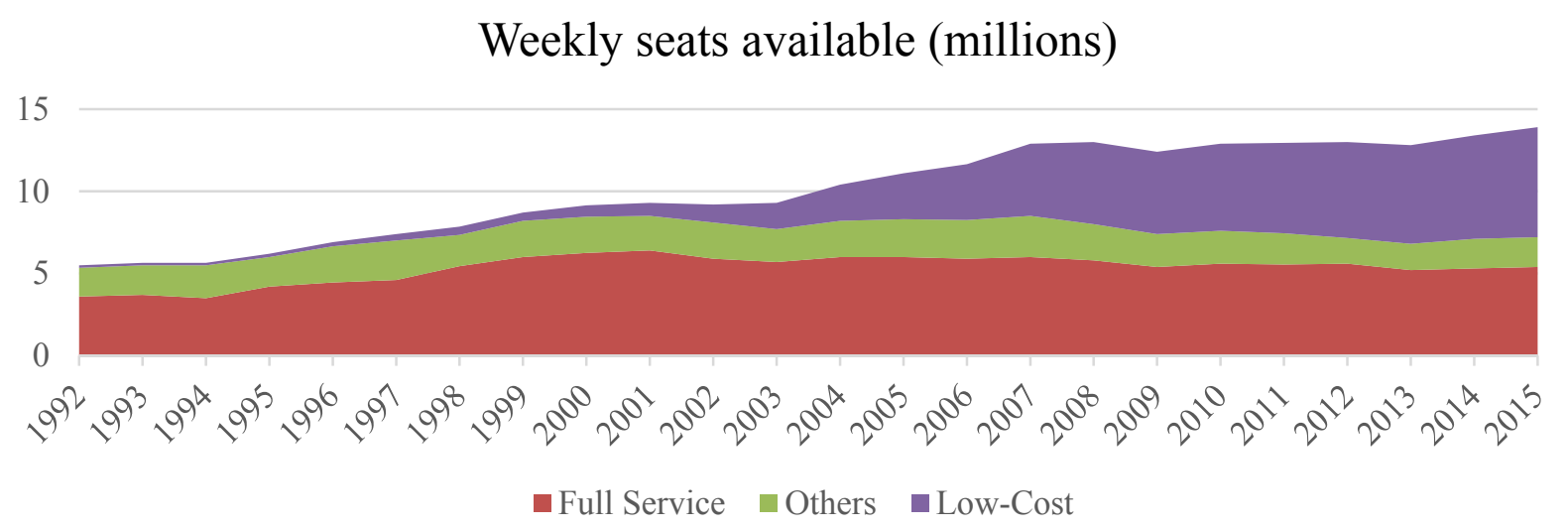

Figure 1. Evolution of the supply of scheduled seats for the period 1992-2015

(Source: European Commission, 2015)

Research objective and methodology

The specification of Ryanair's low-cost strategy as a blue ocean strategy is directly self-justified even though the concept was not formulated at the time of Ryanair's entry into the market. Štverková et al. (2012) apply this thesis but do not verify the classification in more detail, which is why the first aim of this work is to verify this idea using blue ocean strategy characteristics (Kim and Mauborgne, 2005a).

The competition has grown in this segment because of the entry of other companies into the industry segment along with the changes in the traditional carriers' business models (Reichmuth, 2008; Wensveen, 2012), thereby indicating the time limitation of the blue ocean strategy concept, which is the second topic of this article. In response, Ryanair is gradually changing its business model and extending its operations to the main airports it has previously avoided. The reason for these steps is the limited opportunity for further demand growth in the current segment, because of competition and the weakening of the purchasing power of cost-sensitive customers as a result of economic stagnation in Europe (Macnamara, 2010; Cauchi, 2013; Wall, 2016). Can the blue ocean strategy affect the future competitiveness of company because of the first-mover advantage for example? This is the third key point in this article.

\subsection{Research questions}

The relevant research questions are

Q1. Does the low-cost strategy applied by Ryanair fulfill the specifics of blue ocean strategy?

Q2. Can we currently refer to blue ocean strategy in the case of Ryanair or is the validity of the strategy limited by the entrance of other competitors?

Q3. Can the blue ocean strategy play a positive role by creating the first-mover advantage in a new industry segment? 


\subsection{Methodology}

The main subject of the survey is the Irish low-cost airline Ryanair, which began to write the history of low-cost transport in Europe in 1990. The first research question examines whether Ryanair's strategy in the 1990s is in line with blue ocean strategy. To do this, the analytical tools and system frameworks developed by the blue ocean strategy authors', Kim and Mauborgne (2005a), are used to classify Ryanair's strategy.

The first step is to create an image of the strategy, that is, a graph of value curves. In the language of the blue ocean strategy authors' Kim and Mauborgne (2005a), European airlines in the early 1990s competed in a red ocean. The boundaries of the civil aviation industry had been firmly defined, the rules of competitive combat are clear, and the market is consolidated (Reichmuth, 2008; Wensveen, 2012). On this basis, the following simplistic assumption was made: traditional airlines in Europe formed an outwardly homogeneous group as the standard was set and the business models did not differ significantly.

The same was assumed for charter airlines. Representatives were selected from both the airline categories, namely, British Airways as the representative for traditional carriers and Thomson Airways as the representative for charter companies. We are aware of the limitations of this simplification but believe that because of the previously mentioned consolidation of the industry, it does not have a significant impact on the resulting image of the strategy.

Two value curves, one for British Airways and the other for Thomson Airways, were compiled as the image of the strategy. A set of indicators representing the essence of competitive behavior in European civil aviation before the arrival of low-cost airlines is presented on the $\mathrm{X}$-axis (Reichmuth, 2008; Wensveen, 2012) and includes

- Offer of a loyalty program,

- Offer of differentiated travel classes,

- Onboard services included in the ticket price,

- Luggage weight included in the ticket price,

- Onboard atmosphere and comfort,

- Time accuracy.
The values representing the level of supply provided to customers are shown on the Y-axis. The assessment is quantified using a 0 - to 5 -point scale rating to ensure the validity of this approach and to limit a subjective view influence. Zero points indicate that the company does not address this factor at all, 1 point is a very low level of factor fulfillment, and 5 points is the highest possible level of fulfillment. Values are assigned based on the information from the following sources: the level of the loyalty programs offered, travel class offers, and the checked-in luggage offer are compared to the best offer provided by the best airlines in the world. The source of the data is the websites and annual reports of individual companies. The onboard atmosphere and comfort ratings are based on secondary data, the market research results are from the UK independent consumer organization "Which?," while the information on airline time accuracy is from the US FlightStats analysis.

The second step is based on the application of the system framework of four active measures in order to consider alternative options of customer value. By comparing company business models, potential change factors are identified and compared to Ryanair's strategy. Subsequently, the results are integrated into a strategy image to show whether Ryanair has created a blue ocean. The frequently criticized weak point of the model - the lack of prescription ability - does not affect our results because of a conscious retrospective view of Ryanair strategy.

To answer the second question of whether the validity of the blue ocean strategy is time limited, it is observed if Ryanair has remained alone on the market. If more than one company uses a similar strategy, then blue ocean ceases to be the case.

As a source for monitoring the growth of low-cost carriers, the International Civil Aviation Organization (ICAO) report on low-cost airlines and specialized Internet search engines for low-cost flights across Europe were used. The limitation of this attempt results from a subjective classification that the company uses a low-cost strategy and from the assumption that as such, these companies represent the European low-cost airline industry segment. 
A critical approach used to classify companies into that category may cause lower numbers of direct competitors to be considered. New value curves are created for selected competitors and compared to the Ryanair value curve. The principle of creating value curves is analogous to that applied in previous cases. The comparison included easyJet, which was Ryanair's first major competitor in the mid-1990s and which has a significant position on the current lowcost airline market in Europe, and the Hungarian company Wizz Air, which started a decade later and represents strong competition on the Central and Eastern European market. We assume a strong similarity in the offers from this group of carriers (Reichmuth, 2008; Barrett, 2011; Mills, 2016). The sources of information were the companies' websites, annual reports, and the market analyses of the UK independent consumer organization "Which?" and the US FlightStats.

The third question addresses the topic of the company's further presence on the market, which has become highly competitive. In order to assess the competitive position of the company, the market shares and profits of the companies operating on this market segment are compared. The sources of information were the companies' websites and annual reports.

\section{$4 \quad$ Results and discussion}

\section{Q 1: Validation of blue ocean strategy}

The first topic is to determine the image of the prevailing strategy in the industry before the start-up of low-cost airlines. The first step is to determine the customer value of each factor by using a scale from $0-5$ points.

\section{- Loyalty programs}

To assess the level of the loyalty club offered by British Airways, called the British Airways Executive Club (British Airways, 2017e), a comparison was made with the three airlines ranked among the best in the world, which determines the quality standard according to the international organization (Skytrax, 2016a).

The latest research ran from August 2015 to May 2016 and covered more than 280 airlines. More than
19 million questionnaires were completed, measuring 41 key indicators (Skytrax, 2016b). The Emirates Airline, Qatar Airways, and Singapore Airlines ranked consistently high (Zhang, 2017) and their loyalty programs were compared to the British Airways Executive Club. Airline loyalty programs are based either on miles flown or on customer's money, which is reflected by the points earned (The Luxury Travel Expert, 2015). Emirates Skywards and KrisFlyer belonging to Singapore Airlines use the first system while Qatar Airways Privilege Club and British Airways Executive Club use the second.

Owing to the unequal scale, it is not obvious at first glance to see how difficult it is to qualify for each type. Using the calculators available on these companies' websites, a return flight in economy class from London to Dubai was chosen for a passenger with basic loyalty membership types of blue at British Airways, burgundy at Qatar Airways, blue at Emirates, and KrisFlyer at Singapore Airlines. Subsequently, it was recalculated how many of these flights are needed to qualify for a higher level of membership. The result is shown in Table 1.

The most difficult shift between the membership levels is for the Emirates Skywards members who would have to travel six times and who earn the least bonus miles on this flight followed by Singapore Airlines' KrisFlyer with four routes. However, it should be noted that the benefits of KF Silver Elite membership do not match the level of other airlines and the relevant offer is offered by KF Gold Elite (Singapore Airlines, 2017a; 2017b). British Airways and Qatar Airways showed to be comparable in the test (Oneworld Alliance, 2017).

The British Airways Bronze Club handicap is that, unlike Silver Clubs, Qatar Airways and Emirates, it lacks some benefits, for example, there is no extra weight limit for checked-in luggage and no access to the airport lounges to those members of the Bronze Club who are first class and business class passengers. Alternatively, the benefits of British Airways Silver Club correspond better to the Qatar Airways and Emirates Gold clubs (British Airways, 2017g; Emirates, 2017a; Qatar Airways, 2017a). This is why individual memberships were compared to these levels. 
Table 1. A comparison of the points or miles earned on the London to Dubai return route (Source: British Airways, 2017f; Emirates, 2017c; Qatar Airways, 2017b; Singapore Airlines, 2017c)

\begin{tabular}{|c|c|c|c|rl|}
\hline Club name & Membership type & Travel class & Number of trips & Club Miles collected \\
\hline BA EC & Blue & EC Flexible & 3 & 6960 miles \\
\hline QA PC & Burgundy & EC Flexi & 3 & 6806 miles \\
\hline E SW & Blue & EC Flex & 6 & 4200 miles \\
\hline KF & KrisFlyer & EC & 4 & 6834 miles \\
\hline $\begin{array}{l}\text { Note: BA EC, British Airways Executive Club; QA PC, Qatar Airways Privilege Club; E SW, Emirates Skywards; } \\
\text { KF = KrisFlyer; EC, Economy Class. }\end{array}$
\end{tabular}

The previous comparison shows the high level of the British Airways (BA) Executive Club, which also supports the results of the poll of Business Traveller readers and certified by an independent audit firm. The BA Executive Club has traditionally won the best loyalty program from 2006 to 2016, a period where the results are traceable (Otley, 2016; British Airways, 2017d). The disadvantage is the relatively high fuel surcharges applied to flights realized by loyalty points with British Airways compared to other airlines' loyalty clubs (Johnson, 2015). On the basis of the previous findings, British Airways was subjectively assigned a score of 4.5 points.

The rating of Thomson Airways was very simple, as no comparable loyalty club was offered, so a rating of 0 was awarded.

\section{- Travel classes}

Another factor is the offer and quality of travel classes. The British Airways offer was compared with the Emirates, Qatar Airways, and Singapore Airlines again. As a benchmark, the results of the previously mentioned Business Traveller Awards were used. Singapore Airlines was the most successful because it came first in the economy category and second in the first and business classes. Emirates was first in the first class, second in the economy, and third in the business classes. Qatar Airways came first in the business class while British Airways came third in the first and premium economy categories (Otley, 2016).

For further objectification, the results of the airlines ranking published by The Telegraph were also taken into account, which was based on questionnaires completed by passengers from around the world on AirlineRatings.com. The results confirmed Singapore Airlines' high-end travel offer, as it held on to its top three spot in this survey. British Airways was seventh in the first class and ranked tenth in the premium economy category (Kim, 2016). The British Airways value curve in the strategy image for the travel class factor obtained a 4.5 score.

Thomson Airways does not offer a travel class, so it again received a rating of 0 .

\section{- Onboard services included in the ticket price}

The scores for this factor were based on a market survey by the UK independent consumer organization, "Which?" set up in 1957; the organization tests products and services to improve consumer awareness and facilitate their market orientation (Which?, 2017c). The results of the annual airline survey each October involves thousands of airport passengers across the United Kingdom and are published the following January (Which?, 2017b).

The evaluation of onboard refreshments and entertainment from the four most recently available reviews were used. Passengers assess the level of service provided by awarding between 1 and 5 stars. Using the same rating scale, we used the results directly and did not assume a 0 rating because all companies offer various onboard services.

The rating of British Airways and Thomson Airways, including the number of completed questionnaires, is summarized in Table 2. The respondents rated the refreshment level of British Airways as 3 stars and Thomson Airways as 1.8 stars, both calculated as a weighted average rounded to one decimal place, where the weights were the numbers of completed questionnaires. 
Table 2. Evaluation of the refreshment level and number of completed questionnaires (Source: Which?, 2013, 2014, 2015, 2017a)

\begin{tabular}{|l|l|l|l|l|l|l|l|l|l|}
\hline \multirow{2}{*}{ Company } & \multicolumn{3}{|c|}{2017} & \multicolumn{2}{c|}{2015} & \multicolumn{3}{c|}{2014} & \multicolumn{3}{c|}{2013} & Average \\
\hline British Airways & $* *$ & 1,084 & $* * *$ & 983 & $* * * *$ & 1,341 & $* * *$ & 781 & 3 points \\
\hline
\end{tabular}

The level of onboard entertainment was monitored by a survey conducted in October 2014 and published in January 2015. Almost a thousand respondents rated the level of British Airways onboard entertainment as 4 stars. Thomson Airways were awarded 2 stars less based on the responses of more than 700 hundred respondents (Which?, 2014). Both aspects were combined into one factor: the onboard services included in the ticket price. British Airways achieved an average of 3.5 points and Thomson Airways 1.9 points.

\section{- Luggage weight included in the ticket price}

The luggage weight limits of British Airways and Thomson Airways were compared to that of the Emirates, Qatar Airways, and Singapore Airlines. The traditional airlines differentiate the weight limits according to the travel class. Economy class was selected for comparison, and Emirates, Qatar Airways, and Singapore Airlines have a weight limit of $30 \mathrm{~kg}$ per passenger. British Airways passengers can have luggage of up to $23 \mathrm{~kg}$ in economy class at no extra charge, and Thomson Airways passengers can have luggage of up to $15 \mathrm{~kg}$. A simple ratio was used to create the rating scale where $30 \mathrm{~kg}$ represents 5 points. British Airways achieved 3.8 points and Thomson Airways 2.5 points.

\section{- Onboard atmosphere and comfort}

The assessment of the onboard atmosphere and comfort is based on the results of the market survey conducted by "Which?" again (Table 3; Which?, 2017b). The onboard atmosphere criterion includes the overall cabin environment, that is, cleanliness, light, temperature, and equipment quality. Comfort means seating comfort, legroom, and seat bias. In research published in 2013, both characteristics were assessed globally, and since 2014, these have been monitored separately. The results for individual years were used to calculate the average level of onboard atmosphere and comfort, using the weighted average where the weights were the numbers of completed questionnaires. British Airways' rating was rounded to 3.6 points on a 5-point rating scale. Thomson Airways achieved a level of 2.5 points.

Table 3. Assessment of the onboard comfort and atmosphere (Source: Which?, 2013, 2014, 2015, 2017a)

\begin{tabular}{|c|c|c|c|c|}
\hline \multirow{2}{*}{ Year } & \multicolumn{2}{|c|}{ British Airways } & \multicolumn{2}{c|}{ Thomson Airways } \\
\cline { 2 - 5 } & Atmosphere & Comfort & Atmosphere & Comfort \\
\hline 2017 & $* * *$ & $* * *$ & $* * *$ & $* *$ \\
\hline 2015 & $* * * *$ & $* * *$ & $* * *$ & $* *$ \\
\hline 2014 & $* * * *$ & $* * * *$ & $* * *$ & $* *$ \\
\hline 2013 & \multicolumn{2}{|c}{$* * * *$} & \multicolumn{2}{|c|}{} \\
\hline
\end{tabular}

\section{- Time accuracy}

An aircraft flies on time unless it is delayed by more than 15 minutes according to generally accepted industry standards (Booz \& Hamilton, 2001). Airlines and airports typically publish the percentage of accurate flights. The data on the time accuracy of British Airways are taken from their annual re- 
ports (British Airways, 2013, 2014, 2015, 2016a, 2017c). The data of Thomson Airways are collected from Flightontime.info, which conducted a detailed analysis of time delays at 24 major airports in the United Kingdom since 2003 using the data provided by the British Civil Aviation Authority (Flightontime, 2017). As the server analyses only the UK airports, it is not applicable to all British Airways flights and the data do not match the company's overall results published in the annual reports.

In the case of the Thomson Airways charter airline, all its links connect a variety of destinations solely to the UK airports so the information is relevant.

The accuracy of information of both the airlines from 2011 to 2015 is shown in Table 4.

Table 4. Time accuracy of selected airlines

(Source: British Airways, 2016b; Flightontime, 2015; Ryanair, 2017c; Wizz Air, 2016)

\begin{tabular}{|l|c|c|c|c|c|c|}
\hline & 2011 & 2012 & 2013 & 2014 & 2015 & Average \\
\hline British Airways & $83 \%$ & $79 \%$ & $76 \%$ & $79 \%$ & $78 \%$ & $79 \%$ \\
\hline Thomson Airways & $77 \%$ & $81 \%$ & $79 \%$ & $74 \%$ & $72 \%$ & $76 \%$ \\
\hline easyJet & $84 \%$ & $87 \%$ & $88 \%$ & $87 \%$ & $82 \%$ & $86 \%$ \\
\hline \multicolumn{2}{|l|}{ Wizz Air } & & & $84 \%$ & $84 \%$ \\
\hline
\end{tabular}

Accuracy for all flights is impossible, so the benchmark has been based on the list of the most and the less accurate airlines in the world, according to FlightStats (2017). The best airlines had just below $90 \%$ and the worst had only $30 \%$ accuracy (Plush, 2017). These data were used as the upper and lower limits of the rating scale. Airline companies were awarded 0 points for accuracy of $30 \%$ or less and those with $90 \%$ accuracy were awarded 5 points. The differences between points were $12 \%$. On the basis of this method, British Airways received 4 points and Thomson Airways received 3.8 points.

British Airways and Thomson Airways value curves were compiled from these figures and represent a basic aviation strategy image of the civil airways in Europe before the arrival of low-cost air carriers. Figure 2 illustrates the strategic profiles of traditional airlines, represented by British Airways, and the charter airlines represented by Thomson Airways. The British Airways value curve suggests a differentiation strategy, whereas the shape of the Thomson Airways curve suggests a low-cost strategy (Porter, 1998). However, the important result is that both curves have a similar basic shape and that the strategies of both airlines vary only in the different level of service.
To create a blue ocean, it is necessary to change strategic thinking and reassemble the set of factors offered to the customer. Be aware of what the current customer really requires and what would attract current noncustomers using other forms of transport. For a new definition of the problem and an outline of the strategic profile of the service, a system framework of four active measures was used (Kim and Mauborgne, 2005a).

To create a blue ocean, Ryanair could have theoretically answered the four basic questions mentioned in the theoretical background. The first question seeks to identify the factors that are considered to be standard in the sector but should be discarded (Kim and Mauborgne, 2005a; 2009). For Ryanair, such a factor was the loyalty program offer. The company was convinced of this in 1988-1989 when it was operating as a regional airline but soon closed the program (Ryanair, 2015a).

The system of travel classes with respect to a homogeneous fleet, an attempt to maximize onboard capacity, and the pricing policy of the low-cost airline all met a similar fate. Another factor that Ryanair apparently considered undesirable for short-haul destinations was the onboard services offer. 
The second question concerned factors that would have been appropriate at a significantly lower level (Kim and Mauborgne, 2005a). As such, the factor for onboard atmosphere and comfort were assessed. Perfect cleanliness on board is difficult to achieve in the short time between two flights, so the company exchanged the traditional padded seats for leatherette seats that can be cleaned in a shorter time. The level of comfort was also reduced when Ryanair added another row of seats. Ryanair's last lowered factor was a limit on the luggage included in the ticket price, with only $10 \mathrm{~kg}$ hand baggage permitted (Ryanair, 2017a).

The third question addressed the discovery of factors that should be raised (Kim and Mauborgne, 2005a). Air transport is the fastest form of transport that is inconsistent with frequent delays and has additional time costs resulting from the time needed to get to the airport, pass through various checks, and so on. Ryanair focuses on increasing the percentage of flights without delay and is presented as the most reliable airline in Europe (Ryanair, 2017c).

The most creative answer required the last question concerning the factors that should be created as the existing industries did not address them and should become a new source of customer value (Kim and Mauborgne, 2005a). The answer is based on how Ryanair presents itself externally and what distinguishes it from British Airways and Thomson Airways and other traditional and charter airlines. This is in the price of flights and Ryanair presents itself as an airline with low ticket prices (Ryanair, 2015a). As a further factor, the company created a wider range of destinations. Charter airlines are limited to certain destinations and the offer of traditional airlines is varied but limited to the main airports in the given areas. Ryanair focuses solely on Europe and covers as many smaller secondary airports as possible.

\section{- Ryanair's images of strategies}

To create an image of the new strategy, Ryanair was assigned a score for the original factors, and the score for the new factors was allocated to all three companies. The scores for the first four factors were unambiguous as Ryanair has discarded these factors and, therefore, earned minimal value. For onboard atmosphere and comfort, the same analogical method was used when assessing British Airways and Thomson Airways with the results based on the market survey conducted by Which?. The company did not achieve more than two stars over the reviewed time horizon and scored just one star for comfort in 2017 (Which?, 2014, 2014, 2014, 2017a). Another factor was time accuracy. The data were collected from the website (Ryanair, 2017c). The same metric was again used for assessment, and Ryanair received 5 points for $90 \%$ accuracy.

A scope of destinations evaluation was based on the search of individual airlines' websites. First, the offers of the companies, previously used to set a benchmark for the supply level of the previous factors, were assessed. Both Emirates and Qatar Airways fly to approximately 150 global destinations (Emirates, 2017b; Qatar Airways, 2017c). Then, the offers of three leading European airlines were taken into account to set a benchmark for the common scope of European destinations. Lufthansa flies to 113 destinations across Europe; Air France and KLM to more than 50 European destinations (AirFrance, 2017; KLM, 2017; Lufthansa, 2017b); British Airways' offer includes 106 European destinations in 31 countries (British Airways, 2017b); Thomson Airways flies to 63 destinations in 9 European countries (Thomson, 2017); Ryanair connects 184 European destinations in the 31 states (Ryanair, 2015a). Again, to compare and confirm an adequate level of the rating scale, the number of destinations offered by the second largest low-cost airline, easyJet, which has lines connecting 123 destinations in 27 European countries (easyJet, 2017b), was taken into account. Ryanair offers the widest range of destinations and scored 5 points; the number of destinations thus formed the upper limit of the rating scale. The nearby points then differ for the 37 destinations. Therefore, British Airways achieved 2.9 points and Thomson Airways 1.7 points.

The level of attractiveness of the prize was obtained by comparing the price of tickets for a specific route on the same date. Return flights from London to Prague, Dublin, and Rome were scheduled from September 4 to 8, 2017. Thomson Airways was not included as it is a charter airline offering specific service packages so the comparison would be irrele- 
vant. At present, the company has also started to sell air tickets but in the 1990s, this was not a common practice. Ticket prices in EUR for British Airways (economy class) and Ryanair are summarized in Table 5.

Table 5. Ticket prices for British Airways, Ryanair, train, and bus on selected routes

(Source: British Airways, 2017a; Checkmybus, 2017; GoEuro, 2017; Ryanair, 2017b; Voyages-sncf, 2017)

\begin{tabular}{|c|c|c|c|c|}
\hline Return ticket from London to & British Airways & Ryanair & Train & Bus \\
\hline Prague & 798.0 & 67.8 & 285.0 & 71.0 \\
\hline Dublin & 564.3 & 68.9 & 98.3 & 88.7 \\
\hline Roma & 892.5 & 92.6 & 420.0 & 260.0 \\
\hline
\end{tabular}

Note: Ticket prices from April 7, 2017, when tracking took place. The train ticket represents a combined price of several companies as none offer the connection by itself. The bus ticket represents the usual price offered by several carriers.

As Ryanair also targeted noncustomers, other forms of public transport were taken into account. The train connection between London and Prague was offered by Trainline platform. The return ticket would cost $€ 285$, although the prices of different connections vary significantly. The one-way ticket price ranges from $€ 104$ to $€ 496$, with an average travel time of around 19 hours and 20 minutes (Trainline, 2017). The bus ride takes a similar time and the return line from Prague to London is $€ 71$ with the Student Agency (Student Agency, 2017; Trainline, 2017). A similar situation occurs on the London - Dublin and London - Rome line. Owing to the price-totravel time ratio, Ryanair achieved 5 points on the rating scale. British Airways, compared to the prices of other forms of transport, but especially when compared to a low-cost rival, achieved 1 point.

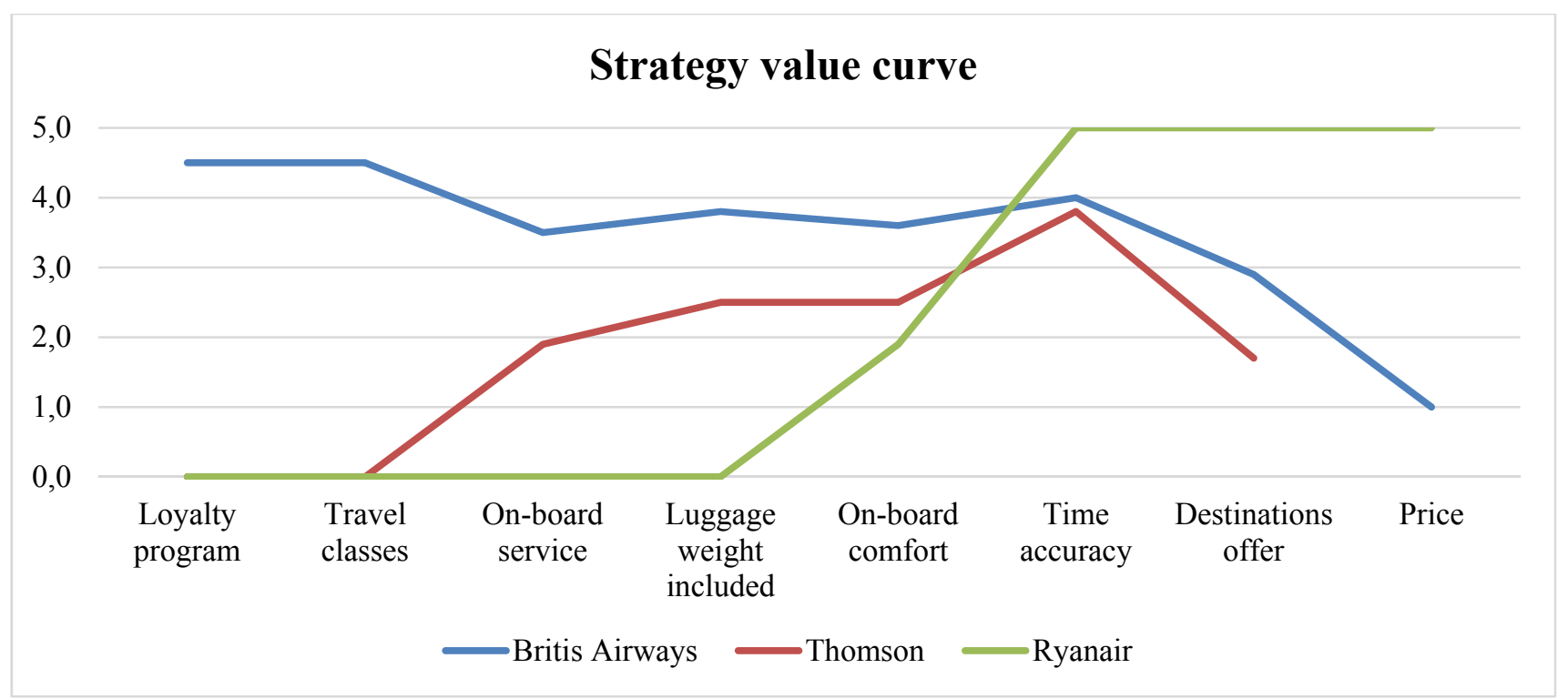

Figure 2. The image of the European aviation industry strategy after the arrival of low-cost airlines (Source: own construct)

Fig. 2 shows that Ryanair's value curve is completely different to potential competitors. Obviously, there is a very different shape to this curve, which suggests that Ryanair has discovered the sovereign market space. The success of Ryanair's blue ocean strategy can be demonstrated, for example, when comparing the number of passengers. Fig. 3 shows a comparison of Ryanair with British Airways. 


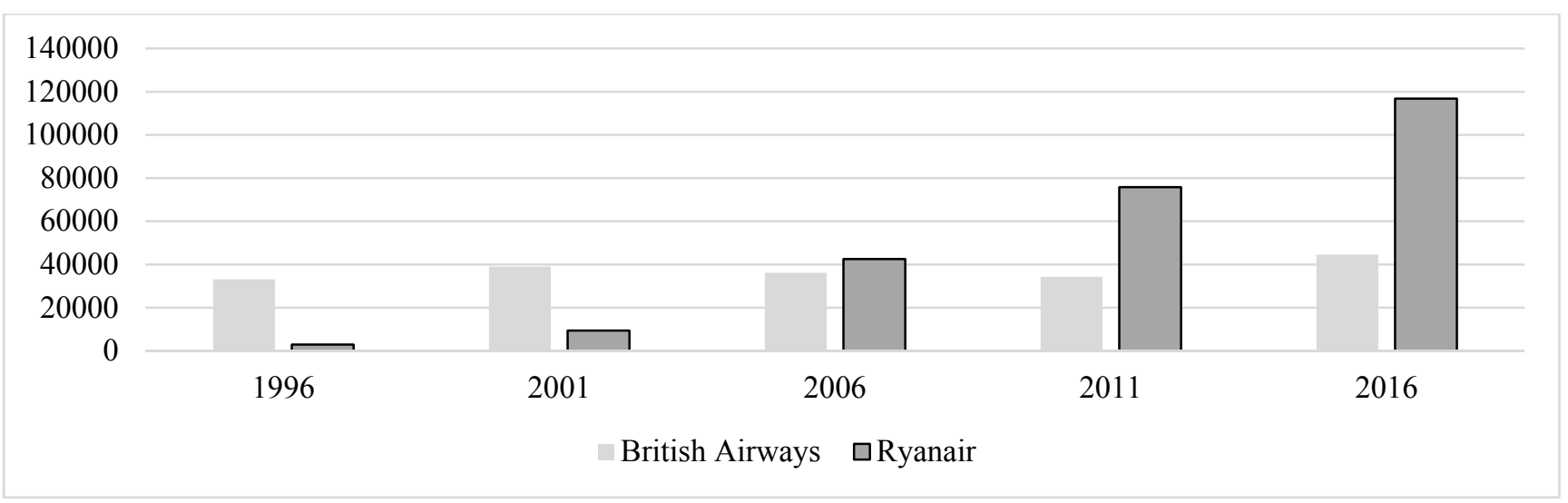

Figure 3. The image of the European aviation industry strategy after the arrival of low-cost airlines (Source: British Airways, 2013; 2017c; Ryanair, 2015a; 2016)

Q2. Can we currently refer to blue ocean strategy in the case of Ryanair or is the validity of the strategy limited by the entrance of other competitors?

As the theory shows, if competitors begin to appear in the blue ocean, the ocean will begin to stain red
(Kim and Mauborgne, 2005a). Airlines with a similar business model can be considered as competitors to Ryanair. Since the transformation of Ryanair into a low-cost airline, similar companies entered the market after just two years. An overview of the emergence of new competitors is presented in Fig. 4.

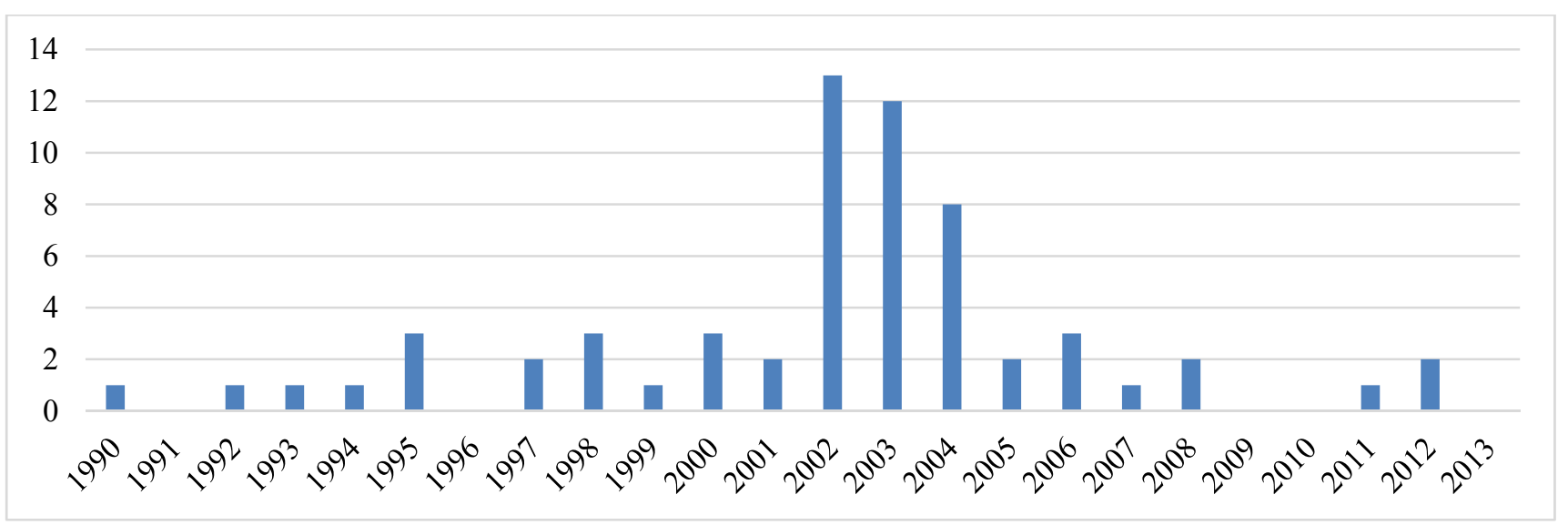

Figure 4. An overview of the emergence of new low-cost airlines in Europe between 1990 and 2013

(Source: ICAO, 2014)

Ryanair strategy has been compared to the strategy of selected competitors, easyJet and Wizz Air. To create a new strategy image, the factor values were set the same as in the previous question. Loyalty programs, travel class systems, onboard service and refreshments, and luggage included in the ticket price were rated zero. The average score of the onboard atmosphere factor and comfort was again based on the ratings of "Which?". easyJet achieved 2.9 and Wizz Air 2.8 points.

easyJet's time accuracy data was taken from Ryanair's website because easyJet does not regularly publish statistics. Wizz Air also does not publish these data on a regular basis and, unfortunately, neither does anyone else, so only data for 2015 were available. As no further data were obtained, this number was taken as the average level, which reduces the validity. An analogous procedure to determine the score as in the previous value curve was used. easyJet achieved a flight accuracy level of 4.6 points and Wizz Air 4.5 points.

The destination offers from both companies were taken from their websites. easyJet connects 123 destinations in 27 European countries (easyJet, 2017b) 
and Wizz Air connects 127 destination in 34 countries (Wizz Air, 2017b), which corresponds to a score of 3.4 points for easyJet while Wizz Air was slightly more successful with 3.5 points.

On the basis of a price comparison of three destination flights using the abovementioned methodology,
easyJet received 4.9, 4.8, and 4.8 points and Wizz Air $4.8,4.9$, and 4.9 points using the average. The strategy image is shown in Fig. 5.

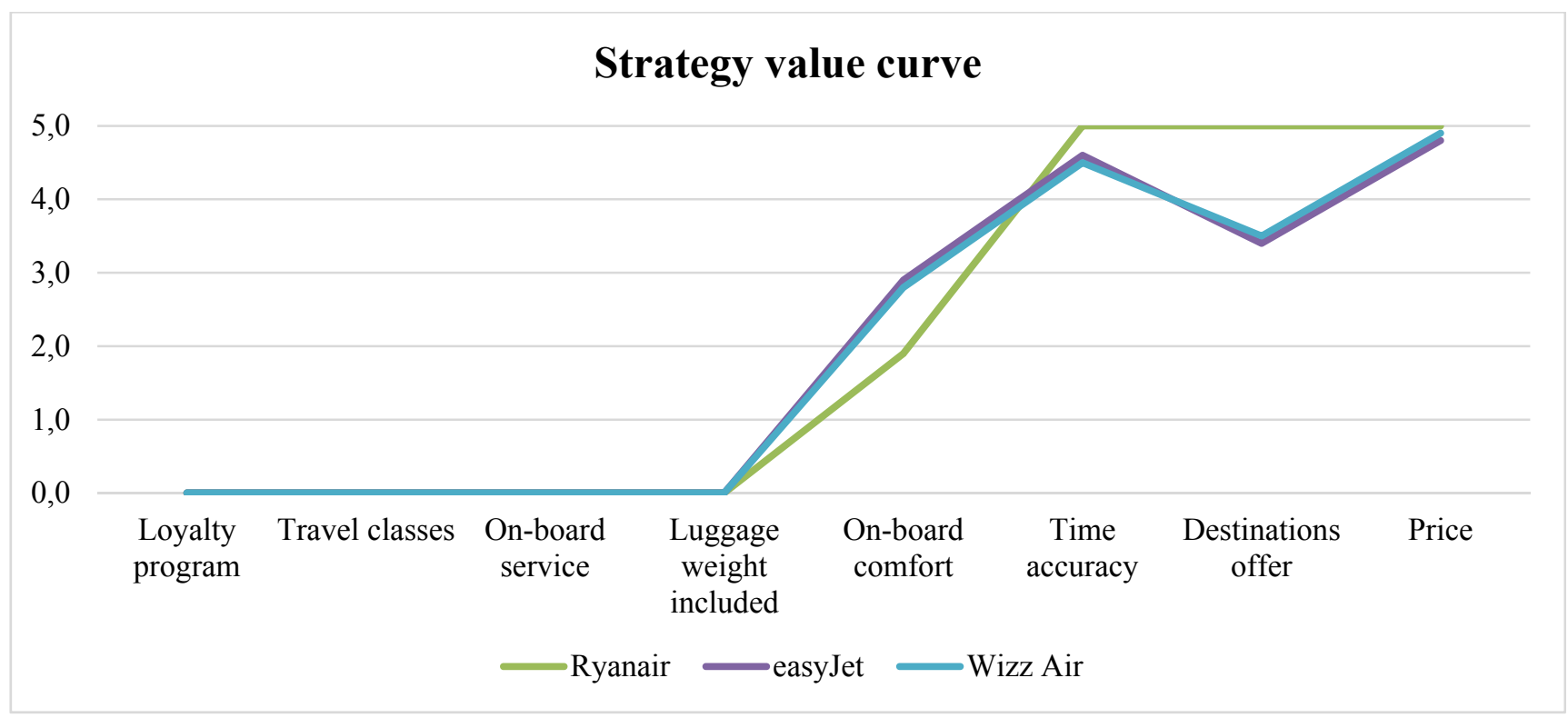

Figure 5. The image of selected European low-cost airlines value strategy

(Source: own construct)

The structure of the easyJet and Wizz Air offers is almost the same in all observed aspects, so the value curves are almost identical. The biggest difference is obvious in the case of the number of destinations, which may be influenced by the size of the companies. The question remains whether a shift to the red ocean is inevitable. This is a topic for further surveys where a larger number of industries should be tested. Basic reasoning suggests that if a new concept appears to be effective, it will attract imitators. An exception may be caused by the creation of sufficient barriers to entry or exhausted market potential.

Q3. Can blue ocean strategy play a positive role by creating the first-mover advantage in a new industry segment?

Data from the report by the International Civil Aviation Organisation (ICAO, 2014) were modified by removing those companies that could not be regarded as low cost. From the 62 companies established since 1990, 43 have now ceased their activities.
This means that in October 2014, when the document was created, only 19 low-cost carriers from the initial list were operating. The list of current European low-cost airlines based on the ICAO inventory and on the information provided by website searches for low-cost flights across Europe shows 17 airlines that can be classified as low-cost airlines. This list may not be complete but all major companies are included.

The sum of the passengers transported by these companies in 2016 was used as the approximate volume of European low-cost air transport, as these low-cost airlines carried more than 321,864 million passengers in 2016. Figure 6 provides an overview of the share of individual carriers in 2016.

We failed to obtain data for Blu-express, Iberia Express, and Volotea, which slightly distorts the results. Current data for Transavia and Vueling were unavailable, so older data had to be used; 2015 data for Transavia and 2014 data for Vueling. 


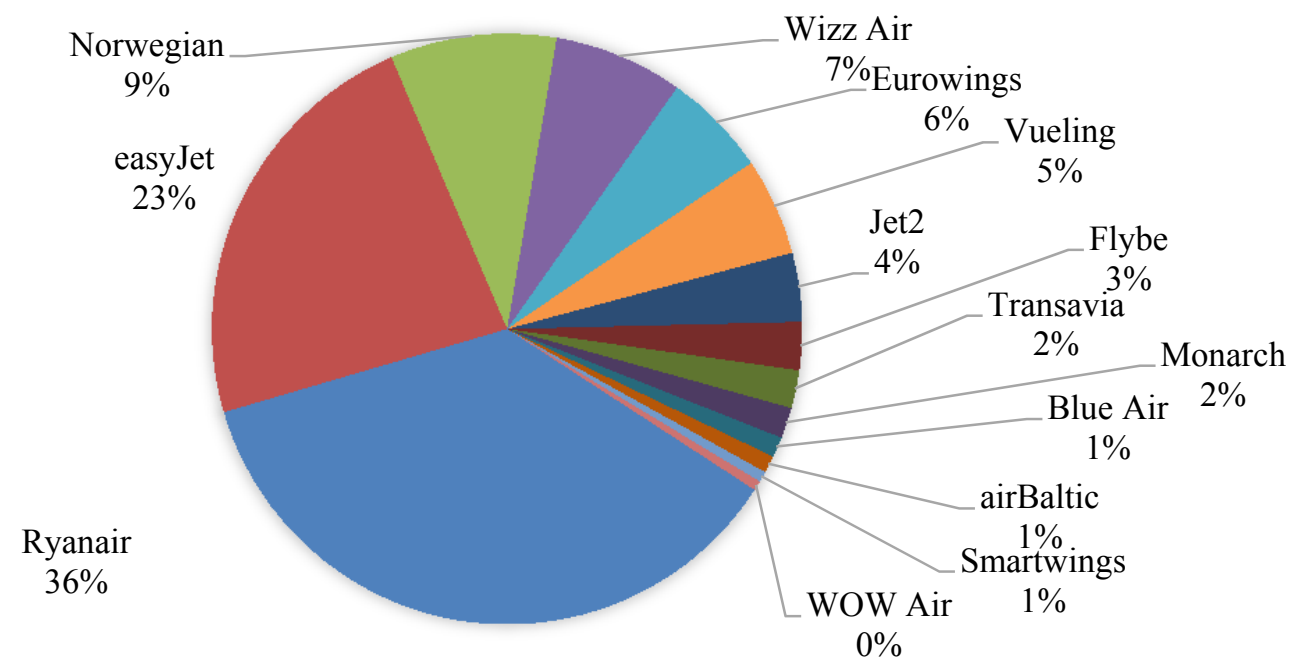

Figure 6. Market share of individual European low-cost airlines

(Source: airBaltic, 2017; CTK, 2017; easyJet, 2017a; ICELAND MAGAZINE, 2017; Lufthansa, 2017a; Norwegian

Air, 2017; Ryanair, 2017d; Stefan, 2017; Transavia, 2016; UK CAA, 2017; Vueling, 2017; Wizz Air, 2017a)

The blue ocean discoverer, Ryanair, continues to hold the dominant market share reaching $36 \%$ and serves a larger segment of the market than the 12 remaining smaller players (not including easyJet and Norwegian). Ryanair also has a more dominant position than easyJet and Norwegian, as they cover $32 \%$ of the market together. This result, together with the steady but constant growth of the low-cost airline industry segment (Figure 1), shows the domi- nant position of Ryanair in the industry segment. Although the blue ocean strategy had limited duration, there is nothing to indicate that Ryanair would be endangered by the entry of competitors, as illustrated in Figure 7, which depicts the development of Ryanair's profits between 2010 and 2016 in comparison with its three biggest competitors (Ryanair, 2016).

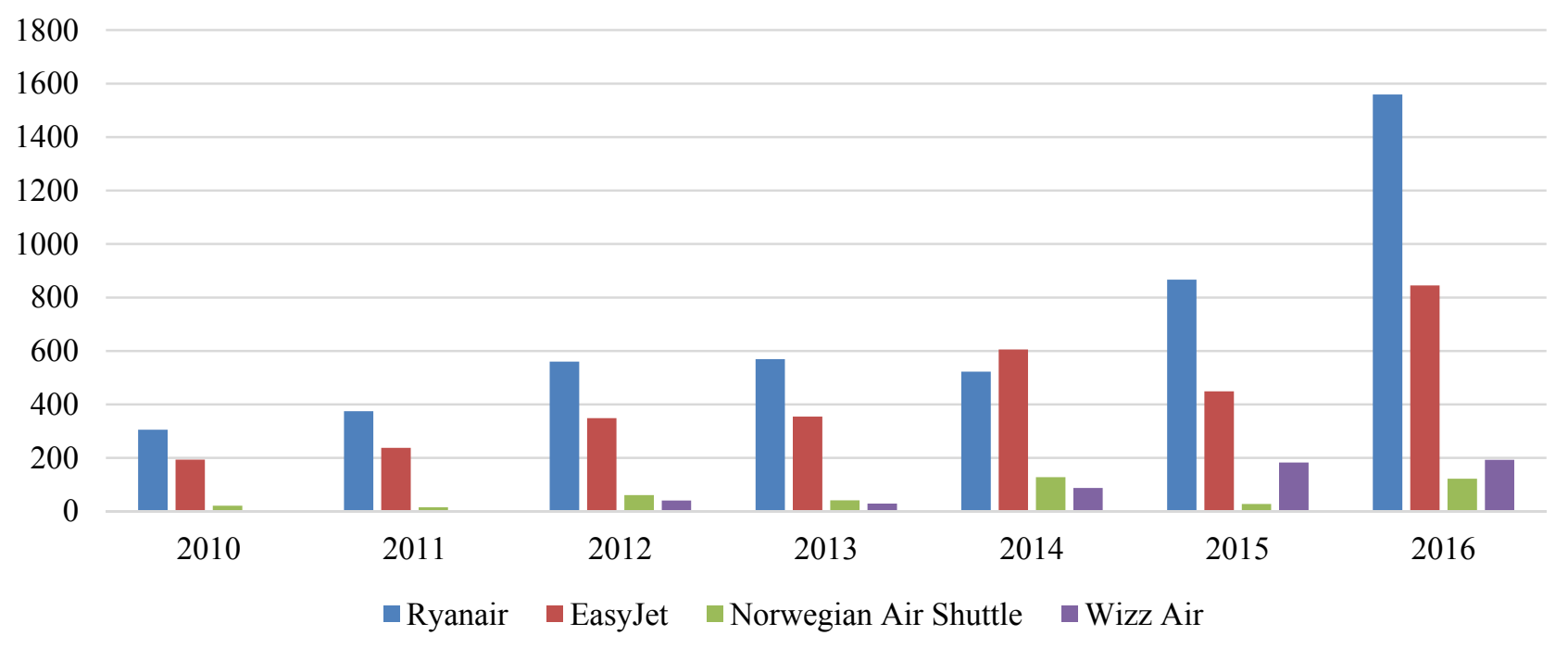

Figure 7. Profits of selected Airlines in 2010-2016 in million EUR

(Source: easyJet, 2010, 2011, 2012, 2013, 2014, 2015, 2016; Morningstar, 2017; Norwegian Air, 2010, 2011, 2012, 2013, 2014, 2015, 2016; Ryanair, 2010, 2011, 2012, 2013, 2014, 2015b, 2016; Wizz Air, 2015, 2016) 


\section{Conclusion}

Although blue ocean strategy was not consciously used when Ryanair's business model was developed because the idea was actually published several years later, it is clear from our analysis that the idea of the strategy was fulfilled. When creating a new strategy, the whole concept of the service offered was clearly changed, as showed by the new shape of the value curve characterizing the basic features of the newly formulated business offer. The lifetime of this strategy is clearly limited, as evidenced by the rapid growth of competitors who follow a very similar strategy and have gradually gained a significant market position. The significant similarity is again evident from the comparison of the commercial offers of selected competitors. The weaker aspect of the chosen approach is that only selected industry representatives were involved in the research, as the authors relied on the considerable homogeneity of the offers of individual competitor groups in the sector (Doganis, 2006; Wensveen, 2012). Despite the stated homogeneity, the selected method opens up space to verify the conclusions on a broader sample of companies. The last part suggests that the success of the company that first came up with the new concept may not be directly jeopardized by the entry of new direct competitors if this company is able to use the first-mover advantage and firmly establish itself in the market. However, on the basis of one sample, no conclusions can be drawn and this is a subject for further study.

\section{References}

[1] airBaltic., 2017. airBaltic - Growth and Profit in 2016, airBaltic. [online] Available at: https:// www.airbaltic.com/en/airbaltic-growth-profit-20 16 [Accessed 13 November 2017].

[2] AirFrance., 2017. Network Maps, Flight Destinations - Air France Airline [online] Available at: https://www.airfrance.fr/FR/en/local/guidev oyageur/reseau/reseau_airfrance_airfrance.htm [Accessed 11 November 2017].

[3] Ansoff, H. I., 1957. Strategies for Diversification. Harvard Business Review, 35(5), pp.113124.
[4] Barrett, S.D., 2004. The Sustainability of the Ryanair Model. International Journal of Transport Management, 2(2), pp.89-98.

[5] Barrett, S.D., 2011. Ryanair and the Low-cost Revolution. Air Transport in the 21st Century: Key Strategic Developments. Ashgate Publishing, Ltd.

[6] Bonsor, K., 2001, June 14. How Airlines Work. [online] Available at: http://science.howstuff works.com/transport/flight/modern/airline.htm [Accessed 27 June 2017].

[7] Booz, A., and Hamilton., 2001. How Airlines Can Improve Their on Time Performance. Airlines, Strategic Management. [online] Available at: https://www.scribd.com/document/57802039 /How-Airlines-Can-Improve-Their-on-Time-Per formance [Accessed 4 November 2017].

[8] Bower, J. L., and Christensen, C. M., 1995. Disruptive Technologies: Catching the Wave. [online] Available at: https://hbr.org/1995/01/ disruptive-technologies-catching-the-wave [Accessed 28 June 2017].

[9] British Airways., 2013. British Airways Plc Annual Report and Accounts Year ended 31 December 2012. [online] Available at: http://www. iairgroup.com/phoenix.zhtml?c=240949andp= irol-reportsannual [Accessed 4 November 2017].

[10] British Airways., 2014. British Airways Plc Annual Report and Accounts Year ended 31 December 2013. [online] Available at: http://www.iairgroup.com/phoenix.zhtml?c=240 949andp=irol-reportsannual [Accessed 4 November 2017].

[11] British Airways., 2015. British Airways Plc Annual Report and Accounts Year ended 31 December 2014. [online] Available at: http://www. iairgroup.com/phoenix.zhtml?c=240949andp= irol-reportsannual [Accessed 4 November 2017]

[12] British Airways., 2016a. British Airways Plc Annual Report and Accounts Year ended 31 December 2015. [online] Available at: http://www. iairgroup.com/phoenix.zhtml?c=240949andp= irol-reportsannual [Accessed 4 November 2017].

[13] British Airways., 2016b. British Airways - BRITISH AIRWAYS FACTSHEET. [online] Available at: http://mediacentre.britishairways.com/factshe ets/details/86/Factsheets-3/33 [Accesse d 13 November 2017]. 
[14] British Airways., 2017a. British Airways, Flights. [online] Available at: https://www. britishairways.com/en-gb/home\#/ [Accessed 4 November 2017].

[15] British Airways., 2017b. British Airways, Where we fly. [online] Available at: https://www. britishairways.com/travel/where-we-fly/public /en_gb/map [Accessed 13 November 2017].

[16] British Airways., 2017c. British Airways Plc Annual Report and Accounts Year ended 31 December 2016. [online] Available at: http://www. iairgroup.com/phoenix.zhtml?c=240949andp= irol-reportsannual [Accessed 13 November 2017].

[17] British Airways., 2017d. Collecting Avios, Executive Club, British Airways. [online] Available at: https://www.britishairways.com/en-gb/execu tive-club/collecting-avios? source=MNVEXC2 collecting_avios [Accessed 4 November 2017].

[18] British Airways., 2017e. Executive Club, British Airways. [online] Available at: https://www. britishairways.com/en-gb/executive-club [Accessed 4 November 2017].

[19] British Airways., 2017f. Miles and Points Calculator. [online] Available at: https://www. britishairways.com/travel/flight-calculator/public /en_gb [Accessed 13 November 2017].

[20] British Airways., 2017g. Tiers and Benefits, Executive Club, British Airways. [online] Available at: https://www.britishairways.com/en$\mathrm{gb} /$ executive-club/tiers-and-benefits? source= MNVEXC1 tiers and benefits [Accessed 4 November 2017].

[21] Carpenter, M. A., and Sanders, W. G., 2008. Strategic Management: A Dynamic Perspective Concepts [With Access Code]. Prentice Hall PTR.

[22] Cauchi, M., 2013. Corporate News: Ryanair Shifts Strategy to Win More Business Travelers. Wall Street Journal, Eastern Edition; New York, N.Y., p. B.7.

[23] Checkmybus., 2017. Find Cheap Bus Tickets. CheckMyBus. [online] Available at: https:// www.checkmybus.com/\#departureDate=2017$11-20$ andorigin $=$ London $\% 2451.5073509 \% 2 \mathrm{C}$ 0.1277583 anddestination $=$ Rome $\% 2441.901895$ $\% 2$ C12.498747 andsortValue=Departureandsort
Order $=$ ascendingandradius $=15 \quad$ [Accessed 13 November 2017].

[24] CTK., 2017. Travel Service vloni přepravil o 9,6 $\%$ vice cestujicich (Travel Service carried over 9.6\% more passengers last year), ČeskéNoviny.cz. [online] Available at: http:// www.ceskenoviny.cz/zpravy/travel-service-vloni -prepravil-o-9-6-vice-cestujicich/1438548 [Accessed 13 November 2017].

[25] Dagnino, G.B., and Padula, G., 2002. Coopetition Strategy: A New Kind of Interfirm Dynamics for Value Creation. Research Gate. Stockholm. [online] Available at: https://www. researchgate.net/publication/228605296_Coope tition_Strategy_A_New_Kind_of_Interfirm_Dy namics_for_Value_Creation [Accessed 28 June 2017].

[26] Doganis, R., 2006. The Airline Business. Routledge.

[27] easyJet., 2010. 2010 Annual Report and Accounts. easyJet. [online] Available at: http:// corporate.easyjet.com/ /media/Files/E/Easyjet/p df/investors/result-center-investor/easyJet_AR10 _18_1_2011.pdf [Accessed 14 November 2017].

[28] easyJet., 2011. 2011 Annual Report and Accounts. easyJet. [online] Available at: http://cor porate.easyjet.com/ /media/Files/E/Easyjet/pdf /investors/result-center-investor/annual-report2011.pdf [Accessed 14 November 2017].

[29] easyJet., 2012. 2012 Annual Report and Accounts. easyJet. [online] Available at: http://co rporate.easyjet.com/ /media/Files/E/Easyjet/pdf /investors/result-center-investor/annual-report2012.pdf [Accessed 14 November 2017].

[30] easyJet., 2013. 2013 Annual Report and Accounts. easyJet. [online] Available at: http://co rporate.easyjet.com/ /media/Files/E/Easyjet/pdf /investors/result-center-investor/annual-report-2 013.pdf [Accessed 14 November 2017].

[31] easyJet., 2014. 2014 Annual Report and Accounts. easyJet. [online] Available at: http://cor porate.easyjet.com/ /media/Files/E/Easyjet/pdf/ investors/result-center-investor/annual-report-20 14.pdf [Accessed 14 November 2017].

[32] easyJet., 2015. 2015 Annual Report and Accounts. easyJet. [online] Available at: http://cor porate.easyjet.com/ /media/Files/E/Easyjet/pdf/ 
investors/result-center-investor/annual-report-20 15.pdf [Accessed 14 November 2017].

[33] easyJet., 2016. 2016 Annual Report and Accounts. easyJet. [online] Available at: http://cor porate.easyjet.com/ /media/Files/E/Easyjet/pdf/ investors/result-center-investor/annual-report-20 16.pdf [Accessed 14 November 2017].

[34] easyJet., 2017a. easyJet Monthly Traffic Statistics for December 2016. [online] Available at: http://corporate.easyjet.com/investors/traffic-sta tistics/2016/english/dec [Accessed 14 November 2017].

[35] easyJet., 2017b. Route Map, Flights to European Destinations and Beyond, easyJet. [online] Available at: http://www.easyjet.com/EN/route map [Accessed 14 November 2017).

[36] Emirates., 2017a. Emirates Skywards: Membership Tiers, Emirates Skywards. [online] Available at: https://www.emirates.com/english/sky wards/membership_tiers/membership_tiers.aspx [Accessed 4 November 2017].

[37] Emirates., 2017b. Find Flights to Emirates Destinations. [online] Available at: https://www. emirates.com/english/destinations/ [Accessed 5 November 2017].

[38] Emirates., 2017c. Miles Calculator. [online] Available at: https://www.emirates.com/account/ uk/english/miles-calculator/miles-calculator.aspx [Accessed 13 November 2017].

[39] European Commission., 2015. An Aviation Strategy for Europe. European Commission. [online] Available at: http://eur-lex.europa .eu/legal-content/EN/TXT/HTML/?uri=CELEX: 52015SC0261andfrom=IT [Accessed 12 November 2017].

[40] Flightontime., 2015. FLIGHTONTIME.info Thomson Airways Charter and Scheduled Flight Delays and Punctuality. [online] Available at: http://www.flightontime.info/charter/airlines/to m15.html [Accessed 13 November 2017].

[41] Flightontime., 2017. FLIGHTONTIME.info Airline Delays and Punctuality at UK Airports. [online] Available at: http://www.flightontime .info/ [Accessed 4 November 2017].

[42] FlightStats., 2017. About FlightStats. [online] Available at: https://www.flightstats.com/com pany/corporate/about-us/ [Accessed 5 November 2017].
[43] Fu, X., Oum, T.H., and Zhang, A., 2010. Air Transport Liberalization and Its Impacts on Airline Competition and Air Passenger Traffic. Transportation Journal, 49(4), pp.24-41. [online] Available at: https://doi.org/10.2307/40904 912 [Accessed 22 August 2017].

[44] GoEuro., 2017. GoEuro. [online] Available at: https://www.goeuro.com/travel-search2/results/ 658178488/train [Accessed 13 November 2017].

[45] Heijden, K. van der., 2006. Scénárere: uměni strategické konverzace $=$ Scenarios : the art of strategic conversation (John Wiley and Sons). Praha: ASPI.

[46] Hill, C.W.L., and Hult, G.T.M., 2016. International Business: Competing in the Global Marketplace (11th edition). New York, NY: McGraw-Hill Education.

[47] ICAO., 2014. Long-term Forecasts of Scheduled Passenger Traffic. [online] Available at: https://www.icao.int/sustainability/Pages/GATO 2030.aspx [Accessed 5 November 2017].

[48] ICAO., 2016. About ICAO. [online] Available at: https://www.icao.int/about-icao/Pages/default .aspx [Accessed 22 August 2017].

[49] ICELAND MAGAZINE., 2017. Dramatic Growth of Icelandic Airline WOW Air: 130\% Increase in Passengers in 2016. Icelandmag. [online] Available at: http://icelandmag.visir. is/article/dramatic-growth-icelandic-airlinewow-air-130-increase-passengers-2016 [Accessed 13 November 2017].

[50] Johnson, G., Whittington, R., Scholes, K., Regnér, P., and Angwin, D., 2014. Fundamentals of Strategy (3 edition). Pearson Education.

[51] Johnson, H., 2015. The Simple Dollar: Best Frequent Flyer Programs of 2015. [online] Available at: https://search-proquest-com.zdroje. vse.cz/docview/1669819838/citation/E67386D3 A3664556PQ/1 [Accessed 4 November 2017].

[52] Kampa, J.R., Cziulik, C., and Amodio, C.C.E., 2012. A Critical Analysis on the Blue Ocean Strategy and an Approach for Its Integration into the Product Development Process. Product: Management and Development, 10(2). [online] Available at: https://www.blueoceanstrategy .com/bos-elibrary/a-critical-analysis-on-the-blue -ocean-strategy-and-an-approach-for-its-integra 
tion-into-the-product-development-process/ [Accessed 28 June 2017].

[53] Kim, S., 2016. Revealed: The Best Airlines for First Class, Business Class and Economy Cabins. The Telegraph. [online] Available at: http:// www.telegraph.co.uk/travel/news/revealed-thebest-airline-cabins-for-first-class-business-econ omy/ [Accessed 4 November 2017].

[54] Kim, W.C., and Mauborgne, R., 2005a. Blue Ocean Strategy: How to Create Uncontested Market Space and Make Competition Irrelevant (1 edition). Boston, Mass: Harvard Business Review Press.

[55] Kim, W.C., and Mauborgne, R., 2005b. Value Innovation: a Leap into the Blue Ocean. Journal of Business Strategy, 26(4), pp.22-28. [online] Available at: https://doi.org/10.1108/027566605 10608521 [Accessed 5 November 2017].

[56] Kim, W.C., and Mauborgne, R., 2009. Blue Ocean Strategy: From Theory to Practice. California Management Review, 47. [online] Available at: https://doi.org/10.2307/41166308 [Accessed 5 November 2017].

[57] KLM., 2017. Navigation page - Destination KLM.com. [online] Available at: https://www .klm.com/travel/us_en/destinations/index.htm [Accessed 5 November 2017].

[58] Kraaijenbrink, J., 2012. Four Risks of a Blue Ocean Strategy. [online] Available at: http://thestrategyhandbook.com/four-risks-of-ablue-ocean-strategy/ [Accessed 16 August 2017].

[59] Lufthansa., 2017a. Lufthansa Group, Annual Report 2016. [online] Available at: https://h. fltmaps.com/en?country=XX [Accessed 5 November 2017].

[60] Lufthansa., 2017b. Lufthansa Group Route Map. [online] Available at: https://h.fltmaps.com /en?country $=X X$ [Accessed 5 November 2017]

[61] Macário, R., Reis, V., Viegas, J., Meersman, H., Monteiro, F., Voorde, E. van de, ... Schmidt, H., 2007. The Consequences of the Growing European Low-Cost Airline Sector. Brussels, European Parliament. [online] Available at: http://www.europarl.europa.eu/thinktank/en/doc ument.html?reference=IPOL-TRAN_ET(2007) 397234 [Accessed 23 August 2017].
[62] Macnamara, K., 2010. Ryanair Signals the End of an Era: The Budget Airline's Change in Strategy Could See the Departure of its CEO. Kelly Macnamara Reports. Daily Post; Liverpool (UK). [online] Available at: https://search.proq uest.com/docview/342110366/abstract/E96EBA 0D85294631PQ/4 [Accessed 26 June 2017].

[63] Miles, R.E., and Snow, C.C., 1978. Organizational Strategy, Structure, and Process. New York McGraw-Hill. [online] Available at: http://trove.nla.gov.au/version/50623947 [Accessed 25 August 2017].

[64] Mills, G., 2016. The Airline Revolution: Economic Analysis of Airline Performance and Public Policy (1 edition). London ; New York, NY: Routledge.

[65] Morningstar., 2017. Growth, Profitability, and Financial Ratios for Wizz Air Holdings PLC (WIZZ) from Morningstar.com. [online] Available at: http://financials.morningstar.com/ratios/ r.html?t=WIZZ [Accessed 14 November 2017].

[66] Norwegian Air., 2010. Norwegian Air Shuttle ASA ANNUAL REPORT 2010. [online] Available at: https://www.norwegian.com/globalassets /ip/documents/about-us/company/investor-relati ons/reports-and-presentations/annual-reports/nor wegian-as-asa-annual-report-2010.pdf [Accessed 14 November 2017].

[67] Norwegian Air., 2011. Norwegian Air Shuttle ASA ANNUAL REPORT 2011. [online] Available at: https://www.norwegian.com/globalassets /ip/documents/about-us/company/investor-relati ons/reports-and-presentations/annual-reports/nor wegian-as-asa-annual-report-2011.pdf [Accessed 14 November 2017].

[68] Norwegian Air., 2012. Norwegian Air Shuttle ASA ANNUAL REPORT 2012. [online] Available at: https://www.norwegian.com/globalassets /ip/documents/about-us/company/investor-relati ons/reports-and-presentations/annual-reports/nor wegian-as-asa-annual-report-2012.pdf [Accessed 14 November 2017].

[69] Norwegian Air., 2013. Norwegian Air Shuttle ASA ANNUAL REPORT 2013. [online] Available at: https://www.norwegian.com/globalassets /ip/documents/about-us/company/investor-relati ons/reports-and-presentations/annual-reports/nor wegian-as-asa-annual-report-2013.pdf [Accessed 14 November 2017]. 
[70] Norwegian Air., 2014. Norwegian Air Shuttle ASA ANNUAL REPORT 2014. [online] Available at: https://www.norwegian.com/globalassets /ip/documents/about-us/company/investor-relati ons/reports-and-presentations/annual-reports/nor wegian-annual-report-2014-printer-friendly.pdf [Accessed 14 November 2017].

[71] Norwegian Air., 2015. Norwegian Air Shuttle ASA ANNUAL REPORT 2015. [online] Available at: https://www.norwegian.com/globalassets /documents/annual-report/nas_annualreport_20 15.pdf [Accessed 14 November 2017].

[72] Norwegian Air., 2016. Norwegian Air Shuttle ASA ANNUAL REPORT 2016. [online] Available at: https://www.norwegian.com/globalassets /documents/annual-report/nas_annualreport_20 16.pdf [Accessed 14 November 2017].

[73] Oneworld Alliance., 2017. Greater Rewards for Frequent Flyers with Oneworld. [online] Available at: https://www.oneworld.com/ffp/memberairline-programmes [Accessed 4 November 2017].

[74] Otley, T., 2016. Business Traveller Awards 2016. [online] Available at: https://www.busi nesstraveller.com/awards/business-traveller-awa rds-2016/ [Accessed 4 November 2017].

[75] Plush, H., 2017. Revealed: The World's Most and Least - Punctual Airlines. The Telegraph. [online] Available at: http://www.telegraph.co. uk/travel/news/revealed-worlds-most-and-leastpunctual-airlines/ [Accessed 5 November 2017].

[76] Porter, M.E., 2008. On Competition. Harvard Business School Pub. [online] Available at: http://books.google.ca/books?id=NK1In7hMK1 AC [Accessed 26 June 2017].

[77] Porter, M. E., 1998. Competitive Advantage: Creating and Sustaining Superior Performance (1 edition). New York: Free Press.

[78] Porter, M. E., 2008. The Five Competitive Forces That Shape Strategy [On-line]. [online] Available at: https://www.youtube.com/watch? $\mathrm{v}=\mathrm{mYF} 2$ FBCvXw $[$ Accessed 31 October 2017].

[79] Prahalad, C.K., and Hamel, G., 1990. The Core Competence of the Corporation. Harvard Business Review, 68(3), pp.79-91.

[80] Qatar Airways., 2017a. Benefits at a Glance. [online] Available at: http://www.qatarairways.
com/PrivilegeClub/benefits+at+glance.page?mid $=3$ andsid $=2$ [Accessed 4 November 2017].

[81] Qatar Airways., 2017b. Mileage Calculator. [online] Available at: http://www.qatarairways. com/PrivilegeClub/MileageCalculator.page?mid $=4$ andsid $=3$ [Accessed 13 November 2017].

[82] Qatar Airways., 2017c. Oneworld, Qatar Airways, Going Places Together. [online] Available at: https://www.qatarairways.com/en/discover. html [Accessed 5 November 2017].

[83] Rao, V., 2007. Book Review: Blue Ocean Strategy. [online] Available at: https://www.ribb onfarm.com/2007/08/06/book-review-blue-ocea n-strategy/ [Accessed 28 June 2017].

[84] Reichmuth, J., 2008. Analyses of the European Air Transport Market: Airline Business Models. German Aerospace Center. [online] Available at: http://ec.europa.eu/transport/sites/transport/fil es/modes/air/doc/abm_report_2008.pdf [Accessed 27 June 2017].

[85] Ryanair., 2010. Ryanair, Annual Report 2010. Ryanair. [online] Available at: https://investor. ryanair.com/wp-content/uploads/2015/04/2012-

Annual-Reports-Annual-Report.pdf [Accessed 14 November 2017].

[86] Ryanair., 2011. Ryanair, Annual Report 2011. Ryanair. [online] Available at: https://investor. ryanair.com/wp-content/uploads/2015/04/2012-

Annual-Reports-Annual-Report.pdf [Accessed 14 November 2017].

[87] Ryanair., 2012. Ryanair, Annual Report 2012. Ryanair. [online] Available at: https://investor. ryanair.com/wp-content/uploads/2015/04/2012-

Annual-Reports-Annual-Report.pdf [Accessed 14 November 2017].

[88] Ryanair., 2013. Ryanair, Annual Report 2013. Ryanair. [online] Available at: https://investor. ryanair.com/wp-content/uploads/2015/04/2013Annual-Reports-Annual-Report.pdf [Accessed 14 November 2017].

[89] Ryanair., 2014. Ryanair, Annual Report 2014. Ryanair. [online] Available at: https://investor. ryanair.com/wp-content/uploads/2015/04/2014Annual-Reports-Annual-Report.pdf [Accessed 14 November 2017].

[90] Ryanair., 2015a. History of Ryanair, Ryanair's Corporate Website. [online] Available at: 
http://corporate.ryanair.com/about-us/history-ofryanair/ [Accessed 27 June 2017].

[91] Ryanair., 2015b. Ryanair, Annual Report 2015. Ryanair. [online] Available at: https://investor .ryanair.com/wp-content/uploads/2015/07/Annu al-Report-2015.pdf [Accessed 14 November 2017].

[92] Ryanair., 2016. Ryanair, Annual Report 2016. [online] Available at: https://investor.ryanair. com/wp-content/uploads/2016/07/Ryanair-Ann ual-Report-FY16.pdf [Accessed 14 November 2017].

[93] Ryanair., 2017a. Baggage, Ryanair's Corporate Website. [online] Available at: https://www.ryan air.com/gb/en/useful-info/help-centre/faq-overvi ew/Baggage [Accessed 5 November 2017].

[94] Ryanair., 2017b. Official Ryanair Website, Book direct for the Lowest Fares, Ryanair.com. [online] Available at: https://www.ryanair. com/gb/en/ [Accessed 13 November 2017].

[95] Ryanair., 2017c. Punctuality, Ryanair's Corporate Website. [online] Available at: http:// corporate.ryanair.com/about-us/punctuality/

[Accessed 5 November 2017].

[96] Ryanair., 2017d. Ryanair, Traffic, Investor Relations. [online] Available at: https://investor. ryanair.com/traffic/ [Accessed 13 November 2017].

[97] Simister, P., 2011. Blue Ocean Strategy by W. Chan Kim and Renee Mauborgne. [online] Available at: http://www.differentiateyourbu siness.co.uk/blue-ocean-strategy-by-w-chan-kim -and-renee-mauborgne [Accessed 16 August 2017].

[98] Singapore Airlines., 2017a. KrisFlyer Elite Gold. [online] Available at: http://www.singap oreair.com/en_UK/sg/ppsclub-krisflyer/krisflyer/ krisflyer-elite-gold/ [Accessed 4 November 2017].

[99] Singapore Airlines., 2017b. KrisFlyer Elite Silver. [online] Available at: https://www.singapore air.com/en_UK/sg/ppsclub-krisflyer/krisflyer/kr isflyer-elite-silver/ [Accessed 4 November 2017].

[100] Singapore Airlines., 2017c. KrisFlyer MileageCalculator. [online] Available at: https:// www.singaporeair.com/kfLogin.form?filterFlow
ExecutionURL $=$ accrualCalculator.form [Accessed 13 November 2017].

[101] Skytrax., 2016a. Introduction to Skytrax. [online] Available at: http://www.worldairline awards.com/main/about_skytrax.html [Accessed 4 November 2017].

[102] Skytrax., 2016b. The World Airline Awards methodology. [online] Available at: http:// www.worldairline.awards.com/Awards/awards_ methodology.html [Accessed 4 November 2017].

[103] Stefan, T., 2017. Aproape 3.6 Milioane Pasageri au ales Blue Air in 2016. [online] Available at: $\mathrm{http}: / /$ aeronews.ro/aproape-3-6-milioane-pasage ri-au-ales-blue-air-in-2016/ [Accessed 13 November 2017].

[104] Student Agency., 2017. RegioJet, Buses and Trains. [online] Available at: https://www. regiojet.com/en [Accessed 5 November 2017].

[105] Štverková, H., Červinka, M., and Humlová, V., 2012. The Impact of Blue Ocean Strategy in Low-cost Transport. Blue Ocean Strategy, Vol. 2012, pp. 40-44). Belgrade. [online] Available at: https://www.blueoceanstrategy.com/academic -articles/the-impact-of-blue-ocean-strategy-in-lo w-cost-transport/ [Accessed 23 August 2017].

[106] The Luxury Travel Expert., 2015. What's the Best Frequent Flyer Program for EU Travelers? [online] Available at: https://theluxurytravel expert.com/2015/05/08/travel-tip-whats-the-best -frequent-flyer-program-for-uk-and-eu-basedtravelers/ [Accessed 4 November 2017].

[107] Thomas, N., 2013. Low-cost Airlines Have Come a Long Way. But Who Will Win the Battle? The Telegraph. [online] Available at: http://www.telegraph.co.uk/finance/newsbysecto $\mathrm{r} /$ transport/10454522/Low-cost-airlines-have-co me-a-long-way.-But-who-will-win-the-battle.ht $\mathrm{ml}$ [Ac-cessed 27 June 2017].

[108] Thomson., 2017. Flights with TUI, Thomson now TUI Airways. [online] Available at: https: //www.tui.co.uk/flight/where-we-fly [Accessed 5 November 2017].

[109] Trainline., 2017. Finally a Better Way to Buy Train Tickets! [online] Available at: https:// www.trainline.eu/?lang=en [Accessed 5 November 2017]. 
[110] Transavia., 2016. Transavia Corporate, Key figures. Corporate.transavia.com. [online] Available at: http://www.transavia.com.s3-websiteeu-west-1.amazonaws.com/ [Accessed 12 April 2017].

[111] UK CAA., 2017. Airline Data December 2016, UK Civil Aviation Authority. [online] Available at: http://www.caa.co.uk/Data-and-analysis/UKaviation-market/Airlines/Datasets/UK-Airline-da ta/2016/Airline-data-December-2016/ [Accessed 13 November 2017].

[112] Voyages-sncf., 2017. Choose Your Train. [online] Available at: https://secure.uk.voyagessncf.com/choose-your-outbound-journey [Accessed 13 November 2017].

[113] Vueling., 2017. Vueling 10 years. Vueling.com. [online] Available at: http://www.vueling.com /en/book-your-flight/find-your-flight [Accessed 13 November 2017].

[114] Wall, R., 2016. Ryanair's New Strategy: Being Nice --- Budget carrier, as a way to win customers, asks its staff to be less confrontational. Wall Street Journal, Europe; Brussels, p. B.1.

[115] Wensveen, D.J.G., 2012. Air Transportation: A Management Perspective. Ashgate Publishing, Ltd.

[116] Which?, 2013. High fliers. Which?, 57(1), pp.30-32.

[117] Which?, 2014. Airlines Best and Worst. Which?, 58(1), pp.21-23.

[118] Which?, 2015. Fly with the best. Which?, 59(1), pp.33-35.

[119] Which?, 2017a. Best and Worst Airlines. Which?, 61(1), pp.23-25.

[120] Which?, 2017b. Best and Worst Airlines. Which? [online] Available at: https://www. which.co.uk/reviews/airlines-and-airports/article /airlines/best -and-worst-airlines [Accessed 4 November 2017].

[121] Which?, 2017c. Who We Are. [online] Available at: https://www.which.co.uk/about-which/whowe-are [Accessed 4 November 2017].

[122] Wizz Air., 2015. Full Year F15 Results. [online] Available at: https://cdn.static.wizzair.com/sta tic/downloads/ipo/Wizz_Air_Holdings_Plc_F15 _Full_Year_Results.pdf [Accessed 13 November 2017].

[123] Wizz Air., 2016. Full Year F16 Results. [online] Available at: https://cdn.static.wizzair.com/sta tic/downloads/IPO/press_releases/F16_Results_ Presentation\%20_25May2016_final.pdf [Accessed 13 November 2017].

[124] Wizz Air., 2017a. Traffic Statistics. [online] Available at: http://corporate.wizzair.com/en-G B/investor_relations/traffic_statistics [Accessed 13 November 2017].

[125] Wizz Air., 2017b. Welcome to the World of Opportunity!, Wizz Air, Destination Map. [online] Available at: https://wizzair.com [Accessed 9 November 2017].

[126] Žabokrtský, M., 2011. EU Air Transport Policy: Implications on Airlines and Airports. Contemporary Europe, (1), pp.161-182.

[127] Zhang, B., 2017. RANKED: The 20 Best Airlines in the World. [online] Available at: http:// uk.businessinsider.com/20-best-airlines-world2017-skytrax-2017-6 [Accessed 4 November 2017]

[128] Zhang, X., Peek, W.A., Pikas, B., and Lee, T., 2016. The Transformation and Upgrading of the Chinese Manufacturing Industry: Based on "German Industry 4.0." The Journal of Applied Business and Economics; Thunder Bay, 18(5), pp.97-105. 